\title{
Effect of Rice Varieties on Growth, Yield and Economics at Varying Levels of Nitrogen under Direct Seeded Upland Condition Rewa Region
}

\author{
Kuldeep Dangi ${ }^{1}$, S.K. Singh ${ }^{2 *}$, D.K. Malviya ${ }^{1}$, A. Gautam ${ }^{3}$, \\ N. Kanapuriya ${ }^{4}$ and Balvendra Kumar ${ }^{5}$ \\ ${ }^{1}$ College of Agriculture, JNKVV, Jabalpur, M.P., India \\ ${ }^{2}$ Food Corporation of India, Regional Office, Patna, Bihar- 800001, India \\ ${ }^{3}$ Assistance Seed Certification Officer, Sagar, M.P., India \\ ${ }^{4}$ College of Agriculture, Rewa, JNKVV, M.P., India \\ ${ }^{5}$ Allahabad University, U.P., India \\ *Corresponding author
}

A B S T R A C T

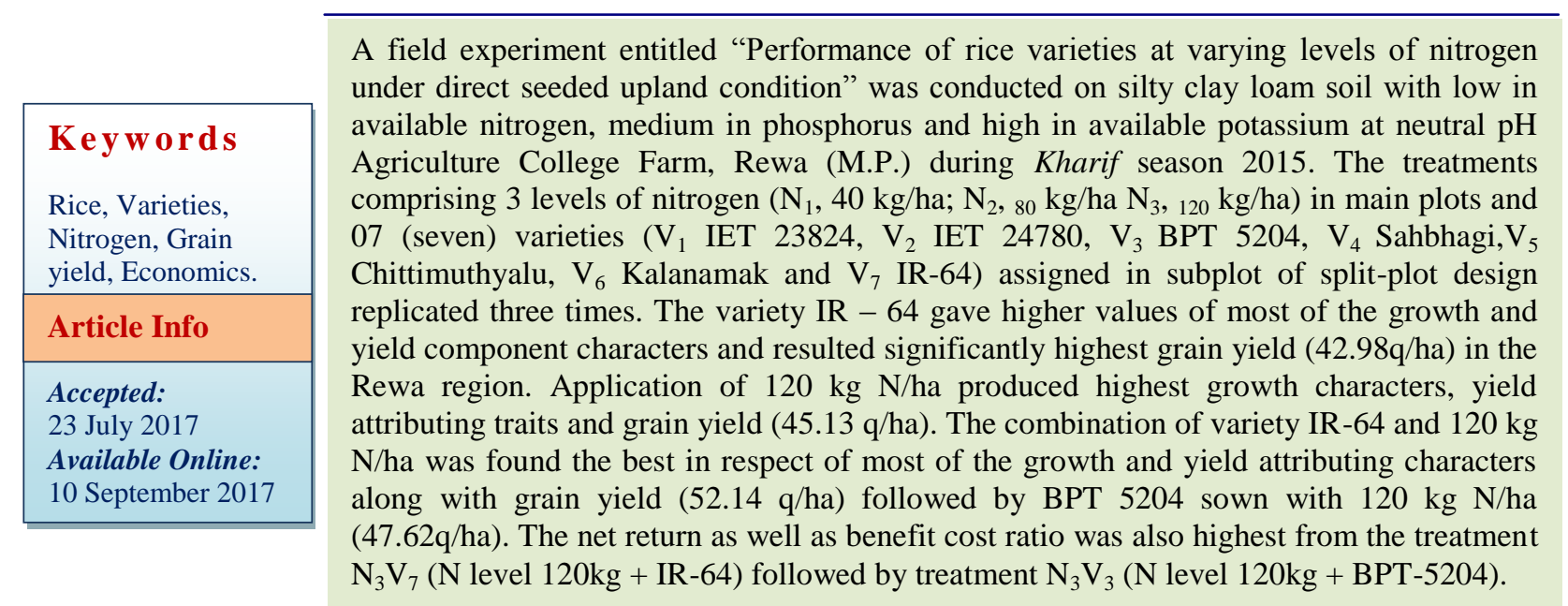

\section{Introduction}

In India rice is cultivated in an area of 44.6 million hectares with the production of 102.0 million tonnes and average productivity of $2286 \mathrm{~kg} / \mathrm{hectare}$ more than half of the rice area is rainfed and distribution wise $80 \%$ of rainfed rice is in eastern India making its cultivation vulnerable to vagaries of monsoon (Anonymous 2014). Madhya Pradesh contributes 1.76 million hectares area under rice with an annual production of 3.02 million tonnes and productivity is $1710 \mathrm{~kg} / \mathrm{ha}$ (Anonymous, 2014).

The main reasons of such low productivity and profitability are vagaries of nature, low fertilizer use efficiency and poor crop management practices including adherence of farmers to the traditional costlier practices, besides low market price of farm produce especially in the recent past. After the 
identification and release of high yielding rice varieties, it becomes imperative to make a comparative assessment of the growth parameters and their influence on grain yields under different nutrient combinations. In nutrient management, nitrogen plays an important role, because it is the major component for protein synthesis and involved in biochemical and physiological activities of plants (Savant and De Datta, 1982). In MP, rice is grown by direct seeding in rainfed uplands with very low productivity ( 0.6 to 0.9 t/ha) due to non-adoption of high yielding varieties and optimum $\mathrm{N}$ levels as compared to national average (1.9 t/ha). In M.P. nearly 17.6 lakh ha area is under rice cultivation of which $80 \%$ in under rainfed condition. The enhanced physiological efficiency of rice genotypes is an indication of their high yielding ability.

In Rewa region rice occupies an area of 135.80 thousand hectare with the production of 367.34 thousand tonnes and productivity is $2705 \mathrm{~kg} / \mathrm{ha}$ (FW\&ADD, 2014). Nitrogen is the key element in the production of rice and gives by far the largest response. It is also a fact that improper use of nitrogenous fertilizers, instead of giving yield advantage, may reduce the same. Again different varieties may have varying responses of $\mathrm{N}$ fertilizer depending on their agronomic traits. Many workers have reported a significant response of rice to nitrogen indifferent soils in Bangladesh (Bhuiyan et al., 2008). It is the most essential element in determining the yield potential and major inputs to rice production. Almost every farmer has tendency to apply costly $\mathrm{N}$ fertilizer in excess to get a desirable yield of Aman rice (Saleque et al., 2004), but imbalance use of $\mathrm{N}$ fertilizer causes harm to the crop and decreases grain yield. Performance of different rice varieties to varying levels of $\mathrm{N}$ have not been evaluated under direct seeded upland rice in Rewa region of Madhya Pradesh.
The importance of early maturing varieties becomes more relevant in context of multiple cropping under upland condition. The productivity of direct seeded upland rice is very low on account of inadequate and imbalance use of nitrogen fertilizers by the farmers, although, nitrogen fertilizers have played an important role in increasing agricultural production and sustainability in upland condition. The information pertaining to nitrogen requirement as well as physiological efficiency of recently available high yielding rice varieties are scanty.

\section{Materials and Methods}

The experiment was carried out at the AICRIP research farm of College of Agriculture. JNKVV. Rewa (M.P.) during kharif season of 2015 to study the Performance of rice varieties at varying levels of nitrogen under direct seeded upland condition. The soil was low in available nitrogen $(236 \mathrm{~kg} / \mathrm{ha})$, medium in phosphorus $(18.5 \mathrm{~kg} / \mathrm{ha})$ and high in available potassium (352 kg/ha) along with 0.62 percentage of carbon/ha. The $\mathrm{pH}$ of the soil was nearly neutral. The field experiment was carried out in split plot design. Twenty one treatment combinations resulting from three nitrogen levels 3 levels of nitrogen $\left(\mathrm{N}_{1}, 40 \mathrm{~kg} / \mathrm{ha} ; \mathrm{N}_{2}\right.$, $80 \mathrm{~kg} / \mathrm{ha} \mathrm{N}, 120 \mathrm{~kg} / \mathrm{ha}$ ) in main plots and 07 (seven) varieties $\left(\mathrm{V}_{1}\right.$ IET 23824, $\mathrm{V}_{2}$ IET 24780, $V_{3}$ BPT 5204, $V_{4}$ Sahbhagi, $V_{5}$ Chittimuthyalu, $\mathrm{V}_{6}$ Kalanamak and $\mathrm{V}_{7}$ IR-64) subplot and replicated thrice. Each of the nitrogen levels were applied through urea containing $46 \% \mathrm{~N}$, in three split doses i.e. $50 \%$ as basal, $25 \%$ at tillering and $25 \%$ at panicle initiation stages as second and third top dressing, respectively. A uniform dose of $40 \mathrm{~kg} \mathrm{P}_{2} \mathrm{O}_{5} /$ ha through single super phosphate $\left(16 \% \mathrm{P}_{2} \mathrm{O}_{5}\right)$ and $20 \mathrm{~kg} \mathrm{~K}_{2} \mathrm{O} /$ ha through murate of potash $\left(60 \% \mathrm{~K}_{2} \mathrm{O}\right)$ was applied as basal in all the plots. The varieties were sown on $4^{\text {th }}$ July, 2015 keeping a seed rate of $50 \mathrm{~kg} / \mathrm{ha}$ 
with row spacing of $20 \mathrm{~cm}$. The total rainfall received during the crop season was 689.2 $\mathrm{mm}$. Other packages of practices rather than treatments were followed as per recommendation for direct seeded rice crop.

\section{Harvest index (\%)}

It is expressed as the ratio of grain yield to biological yield. It was calculated as per following formula:

$$
\text { Harvest index }=\text {--------------------- x } 100
$$

\section{Economics of the treatments}

The cost of production incurred in each treatment was worked out by considering the prevailing market price of input used and the produce obtained (grain and straw) The net income was calculated by subtracting the cost of cultivation from the gross monetary return.

Different values were determined for each treatment as per details given below:

Gross monetary returns $=$ Cost of grain + cost of straw

Net monetary returns $=$ Gross monetary returns - Total cost of cultivation

Benefit: cost ratio $=$ Gross return/Total cost of cultivation

\section{Statistical analysis}

The data recorded on different observations were tabulated and analyzed statistically by using the techniques of analysis of variance (ANOVA) as suggested by Cocharn and Cox (1967). Critical difference at 0.05 probability level was worked out to compare the treatments when $\mathrm{F}$ test was found significant.

\section{Results and Discussion}

\section{Effect of nitrogen}

Nitrogen levels significantly affected the various growth parameter of direct seeded rice at all growth stages of the crop. But variations were not similar in all the growth stages. Increasing levels of nitrogen increased the plant height at all the crop growth stages, and the increase was statistically significant due to $120 \mathrm{~kg} \mathrm{~N} / \mathrm{ha}$ over both lower doses at each crop growth stages. More or less similar effects of nitrogen in accelerating the height of rice plant have been reported by Singh and Kumar (2012 and 2014). Other growth parameters like number of tillers $/ \mathrm{m}^{2}$ and leaves/plant were affected significantly or non- significantly by the doses of nitrogen at all the stages of crop growth. The maximum values of these parameters were recorded with the highest dose of nitrogen $(120 \mathrm{~kg} \mathrm{~N} / \mathrm{ha})$ at all the stages of crop growth. Furthermore differences between any two adjoining levels of nitrogen in respect of these growth parameters were also found significant or non- significantly. The increasing number of tillers and with increasing leaves of nitrogen may be attributed to the fact that nitrogen seems to have played a vital role in the formation of new tissues which are dependent on the protoplasmic structure, cell division and cell elongation. Moreover increase of leaves/plant means increase in the photosynthesis surface area. In fact leaf is the factory for the conversion of energy in to the chemical energy by the process of photosynthesis. These results are in agreement with the findings of Singh and Kumar (2014), Gohain (2014) and Tiwari et al., (2015).

The increasing levels of nitrogen reflected in increased panicles $/ \mathrm{m}^{2}$, panicle length, grains/panicle, number of filled grains/panicle and test weight. 
Table.1 Growth, yield and economics of rice varieties as influenced by nitrogen levels

\begin{tabular}{|c|c|c|c|c|c|c|c|c|c|c|c|c|c|}
\hline Treatments & $\begin{array}{c}\text { Plant } \\
\text { population } \\
\text { /m² length } \\
\text { (15 DAS) }\end{array}$ & $\begin{array}{c}\text { Plant } \\
\text { height } \\
\text { (At } \\
\text { harvest) }\end{array}$ & $\begin{array}{l}\text { Tiller } / \mathrm{m}^{2} \\
\quad \text { (At } \\
\text { Harvest) }\end{array}$ & $\begin{array}{l}\text { Leaves } \\
\text { /plant } \\
\text { (At } \\
\text { Harvest) }\end{array}$ & $\begin{array}{c}\text { No. of } \\
\text { panicles } / \mathrm{m}^{2}\end{array}$ & $\begin{array}{c}\text { Panicle } \\
\text { length } \\
\text { (cm) }\end{array}$ & $\begin{array}{l}\text { Weight } \\
\text { panicle } \\
\text { (g) }\end{array}$ & $\begin{array}{l}\text { Grains/ } \\
\text { panicle }\end{array}$ & $\begin{array}{c}\text { Filled } \\
\text { grains } \\
\text { /panicle }\end{array}$ & $\begin{array}{c}\text { Test } \\
\text { weight } \\
\text { (g) }\end{array}$ & $\begin{array}{c}\text { Grain } \\
\text { yield } \\
\text { (q/ha) }\end{array}$ & $\begin{array}{c}\text { Net } \\
\text { income } \\
\text { (Rs./ha) }\end{array}$ & $\begin{array}{l}\text { B:C } \\
\text { ratio }\end{array}$ \\
\hline \multicolumn{14}{|c|}{ Nitrogen levels (kg/ha) } \\
\hline 40 & 46.68 & 88.59 & 296.62 & 26.41 & 232.36 & 299.52 & 1.63 & 109.24 & 92.48 & 22.54 & 30.19 & 20209.61 & 1.86 \\
\hline 80 & 47.10 & 95.17 & 360.38 & 37.26 & 238.30 & 353.48 & 1.72 & 111.90 & 95.29 & 22.83 & 36.06 & 28226.45 & 2.17 \\
\hline 120 & 47.61 & 98.83 & 450.81 & 46.12 & 246.18 & 444.19 & 1.81 & 119.43 & 102.57 & 22.99 & 45.13 & 40861.82 & 2.66 \\
\hline S.E.(m) & 0.25 & 0.19 & 6.81 & 0.38 & 0.11 & 6.84 & 0.04 & 2.15 & 2.40 & 0.09 & 0.30 & - & - \\
\hline $\begin{array}{l}\text { CD } \\
(\mathbf{p}=\mathbf{0 . 0 5})\end{array}$ & $0.76^{*}$ & $0.58 *$ & 20.43 & $1.13^{*}$ & $0.32 *$ & 20.51 & $0.11 *$ & $6.45^{*}$ & $7.20 *$ & NS & $0.91 *$ & - & - \\
\hline \multicolumn{14}{|l|}{ Varieties } \\
\hline I & 46.87 & 101.16 & 364.78 & 36.00 & 237.54 & 362.89 & 1.71 & 111.44 & 97.22 & 23.11 & 36.53 & 28908.18 & 2.20 \\
\hline II & 47.03 & 95.48 & 379.22 & 37.43 & 238.24 & 377.44 & 1.77 & 115.89 & 101.89 & 23.31 & 37.96 & 30958.02 & 2.28 \\
\hline III & 47.72 & 85.25 & 390.44 & 38.52 & 242.33 & 388.56 & 1.83 & 119.67 & 102.22 & 23.13 & 39.08 & 32462.45 & 2.34 \\
\hline IV & 47.42 & 91.93 & 358.44 & 35.36 & 240.43 & 356.44 & 1.68 & 110.00 & 91.78 & 22.82 & 35.89 & 28045.40 & 2.16 \\
\hline $\mathrm{V}$ & 46.91 & 91.09 & 345.56 & 24.12 & 237.64 & 343.44 & 1.61 & 105.11 & 87.00 & 22.37 & 34.59 & 26236.25 & 2.09 \\
\hline VI & 45.11 & 106.54 & 328.00 & 32.38 & 228.63 & 326.11 & 1.53 & 103.11 & 81.11 & 21.38 & 32.84 & 23750.63 & 1.99 \\
\hline VII & 48.84 & 87.90 & 418.44 & 42.38 & 247.82 & 405.22 & 1.90 & 129.44 & 116.22 & 23.39 & 42.98 & 38000.78 & 2.56 \\
\hline S.E.(m) \pm & 0.61 & 0.23 & 6.26 & 0.26 & 0.24 & 8.40 & 0.04 & 2.20 & 2.07 & 0.34 & 0.22 & - & - \\
\hline $\begin{array}{l}\text { CD } \\
(p=0.05)\end{array}$ & $1.85^{*}$ & $0.69 *$ & 18.77 & $0.79 *$ & $0.73 *$ & 25.21 & NS & $6.60 *$ & $6.22 *$ & 1.01 & $0.65 *$ & - & - \\
\hline
\end{tabular}


Therefore the highest level of $120 \mathrm{~kg} \mathrm{~N} / \mathrm{ha}$ was registered with the maximum number of panicles $/ \mathrm{m}^{2}$ (444.19), panicle length (22.41 $\mathrm{cm}$ ), number of grains/panicle (119.43), weight of panicle $(1.81 \mathrm{~g})$ and number of filled grains/panicle (102.57); which might be due to increased accumulation of photosynthetic from the source to the sink. It is conformity with the findings of Gohain (2014) and Tiwari et al., (2015) who reported the response of rice crop to nitrogen in augmenting the yield attributing characters.

The direct seeded rice produced the lowest grain (30.19 q/ha) and straw (65.29 q/ha) when nitrogen was given at $40 \mathrm{~kg} \mathrm{~N} / \mathrm{ha}$. But grain and straw yields were significantly maximum (45.13 q/ha) grains and $100.52 \mathrm{q} / \mathrm{ha}$ straw yields) in plots receiving $120 \mathrm{~kg} \mathrm{~N} / \mathrm{ha}$ over 80 and $40 \mathrm{Kg} \mathrm{N} / \mathrm{ha}$. Furthermore, increasing doses of nitrogen upto $120 \mathrm{~kg} / \mathrm{ha}$ was apparently associated $120 \mathrm{~kg}$ per hectare dose of nitrogen was decidedly the best as compared to lower doses. Nitrogen is an integral constituent of photo synthetically active pigment, the chlorophyll by virtue of which plants are able to utilize the light, energy and enzyme nucleotides, which play an important role in cell development. Vigorous growth of crop plants with increased fertility is associated with higher sink capacity. Nitrogen fertilization increases photosynthetic activity and translocation of photosynthates which might have promoted the growth and resulted in better partitioning of photosynthates in yield attributes and eventually produced larger sized and more grains of higher weight that ultimately increased the yield. Many workers like $G$ Singh et al., (2008), Singh and Kumar (2012), Singh and Kumar (2014) and Tiwari et al., (2015) have also recorded significant increase in grain yield of rice due to $\mathrm{N}$ application. Harvest index varied from 31.19 to 31.83 percent under different levels of nitrogen without significant margin.

\section{Effect of varieties}

The growth parameters like plant height, number of tillers $/ \mathrm{m}^{2}$ and leaves /plant were significantly influenced by varieties at all the growth stages. At harvest stage the varieties IR - 64, BPT-5204 and IET 24780 produced significantly highest number of tillers and leaves/plant over rest of the varieties. Significantly lowest number of tillers $/ \mathrm{m}^{2}$ along with dwarf plants was produced by variety BPT-5204 and IR-64. However, variety Kalanamak resulted in significantly tallest plant $(106.54 \mathrm{~cm})$ over rest of the varieties. At final stage of the observations, variety IR - 64 and Kalanamak attained the maximum and minimum values of these parameters, respectively. The differences in growth characters due to genotypes may be attributed to their inherent characteristics. The findings corroborate with those of Sumreen et al., (2011) and Thomas and Lal (2012). Yield attributing characters viz. number of panicle $/ \mathrm{m}^{2}$, panicle length, grains/panicle, weight of panicle and number of filled grains/panicle varied significantly due to varieties. Variety IR - 64 produced maximum number of panicles $/ \mathrm{m}^{2}$ (405.22), panicle length $(23.55 \mathrm{~cm})$, number of grains per panicle (129.44), weight of panicle $(1.90 \mathrm{~g})$, number of filled grains per panicle (116.22) and test weight (23.39) while variety Kalanamak attained minimum value of these yield attributing characters. Number of unfilled grains/panicle was significantly lowest (13.58 to 14.61) in IR - 64 and BPT5204 varieties over other varieties. Variety IR 64 being at par with BPT-5204 resulted in significantly highest grain yield (42.98 q/ha) which was 9.07, 11.68, 15.01 and 16.49 percent higher than that produced by BPT5204, IET 24780, IET 23824 and Sahbhaghi, respectively. Straw yield was significantly highest (105.81 q/ha) over rest of the varieties. Kalanamak produced the lowest straw. The variety Chittimuthyalu gave the 
maximum harvest index $(33.80 \%)$ followed by Anjali (33.61\%), while minimum value (28.94\%) observed from IR - 64. These results are in agreement with the findings of Singh and Kumar (2014), Gohain (2014) and Tiwari et al., (2015) (Table 1).

\section{Economics of treatments}

The variety IR - 64 with $120 \mathrm{~kg} \mathrm{~N} / \mathrm{ha}$ gave highest gross and net return along with $\mathrm{B}$ : C ratio (Rs. 88644.35/ha Rs. 50667.35/ha and 3.03 respectively), followed by BPT 5204 fertilized with same dose of nitrogen (Rs. 79923.00/ha, Rs. 44304.00/ha and 2.79 respectively).

\section{References}

Anonymous, 2014. Agricultural census, Directorate of economics and statistics, Department of agriculture and Cooperation, Government of India.

Bhuiyan, M.N.I., Chowdhury JU and Begum J. 2008. Chemical investigation of the leaf and rhizome essential oils of zingiber zerumber (1) Smith from Bengladesh. Bangladesh Journal of Pharmacology 4 (1): 9-12.

Cochran, W.U., and Cox GM. 1967. Experiment Designs, John Willey \& Sons, New York.

Farmer Walfare and Agricultural Development Department 2014. Ministry of Agriculture, Government of M.P.

Gohain, T., 2014. Performance of local rice cultivars under aerobic ecosystem of Nagaland. Annals of Plant and Soil
Research 16 (4): 342-345.

Saleque, M.A., Naher UA, Islam A, Pathan ABMBU, Hossain ATMS and Meisner CA. 2004. Inorganic and organic phosphorus fertilizer effects on teh phosphorus fractionation in wetland rice. Soils. Soil Science Society of America Journal 68 (5): 1635-1644.

Savant, N.K., and Datta SK. 1982. Nitrogen transformation in wetland rice soils. Advances in Agronomy 35: 241-294.

Singh, D., and Kumar A. 2014. Effect of sources of nitrogen growth yield and uptake of nutrients in rice. Annals of Plant and Soil Research 16 (1): 359361.

Singh, S., and Kumar B. 2012. Effect of Nitrification inhibitors and slow release nitrogenous fertilizer of nitrogen use efficiency and yield of paddy. Annals of Plant and Soil Research 14 (1): 10-13.

Sumreen Siddiq, Alia Anayat Aamer, Ali Sattar and Muhammad Yaseen MA. 2011. Response of different rice (Oryza sativa L.) cultivars to different NPK levels in the central cropping zone of Punjab Agricultural Science Digest 3: (3) $155-160$.

Thomas, N., and Lal G ML. 2012. Genetic divergence in rice genotypes under irrigated conditions. Annals of Plant and Soil Research, 14 (1): 109-112.

Tiwari Sandeep, Tiwari Kumar, Kumar Suresh, Zaidi SFA and Ved Prakash. 2015. Response of rice to integrated nitrogen management under SRI method of cultivation. Annals of Plant and Soil Research, 17 (1): 106-108.

\section{How to cite this article:}

Kuldeep Dangi, S.K. Singh, D.K. Malviya, A. Gautam, N. Kanapuriya and Balvendra Kumar. 2017. Effect of Rice Varieties on Growth, Yield and Economics at Varying Levels of Nitrogen under Direct Seeded Upland Condition Rewa Region. Int.J.Curr.Microbiol.App.Sci. 6(9): 2313-2318. doi: https://doi.org/10.20546/ijcmas.2017.609.283 